Arab Univ. J. Agric. Sci., Ain Shams Univ., Cairo, Egypt

29(1), 243 - 262, 2021

Website: http://ajs.journals.ekb.eg

DOI: 10.21608/ajs.2021.54048.1313

\title{
Using Thermochemical Materials as a Heat Source for Poultry Egg Incubation
}

\author{
Shaymaa A Hassan ${ }^{1 *}$, Mubarak M Mustafa ${ }^{1}$, Mahmoud Z El Attar ${ }^{1}$, \\ Marwa Sh Abdo
}

1- Agricultural Engineering Dept, Fac of Agric, Ain Shams Univ, P.O. Box 68 Hadyek Shoubra 11241, Cairo, Egypt

2- Poultry Production Dept, Fac of Agric, Ain Shams Univ, P.O. Box 68 Hadyek Shoubra 11241, Cairo, Egypt

*Corresponding author: shimaa abdelrazek@agr.asu.edu.eg

Received 20 December, 2020

Accepted 19 April, 2021

\begin{abstract}
This study aims to use one thermochemical storage materials system as a heat source for poultry egg incubation. Three types of activated thermochemical storage materials (TCMs) were used as an energy storage medium. These materials are Silica gel self-indicating (blue/pink), commercial white Silica gel, and Natural Zeolite. An open thermochemical system was applied inside a poultry egg incubator. The TCMs were humidified by the vapor produced from the evaporation of the water by an ultra-sonic humidifier at atmospheric pressure. The thermal recovery process aims to release the stored energy in TCMs. Two types of poultry egg incubator used during this study. The first one was the traditional poultry incubator (electricity incubator). The traditional egg incubator dimensions were $57 \times 66 \times 59 \mathrm{~cm}$ with capacity of $125 \mathrm{hen}$ egg76 hatching. The second one was the prototype of a thermochemical poultry egg incubator. The thermochemical poultry egg incubator contained sensors to control and measure the temperature and humidity inside the incubator. The designed incubator egg dimensions were $56 \times 39 \times 28.5 \mathrm{~cm}$, with a capacity of 25 eggs. The total heat losses by the wall and ventilation
\end{abstract}

were 9.8 and $1.5 \mathrm{~W}$, respectively. The heat production by 25 eggs due to metabolic activities was $3.65 \mathrm{~W}$. The total energy needed for the incubation process was $36.09 \mathrm{~W}$. The container of storage material with dimensions of $35 \times 35 \times 5 \mathrm{~cm}$ with $3.5 \mathrm{~kg}$ capacity allocated inside the incubator. The container's surface is covered with aluminum sheet with $0.5 \mathrm{~mm}$ thickness supplied with fins. The egg tray is placed on the aluminum sheet, and the eggs were placed horizontally in the tray. The energy consumption for traditional and thermochemical incubators for 21 days was 19.25 $\mathrm{kWh}$ and $11.2 \mathrm{kWh}$, respectively. The energysaving by thermochemical prototype incubator was $41.8 \%$. The percentage of hatchability for traditional and prototype incubator was $80.9 \%$ and $71.4 \%$, respectively.

Keywords: Energy storage; Hatchability; Incubation; Poultry incubator; Thermochemical system; Thermochemical materials.

\section{Introduction}

The thermochemical system is classified as adsorption and absorption heat storage. The adsorption means the interaction happens between the sorbate (as water usually) particles and the surface of TCMs (Vasta et al 2018). 
The thermochemical system cycle includes endothermic and exothermic reactions; between two reactions, the storing energy happened. The endothermic reaction (charging process) happens by using heat to separate the sorbate from TCMs. After this process, The TCMs is active, and the energy is stored inside it. The sorbate and TCMs are connected one more time by the endothermic reaction (discharging process) (Haji 2010).

Silica gel and Zeolite are most used in the thermochemical system (Hauer 2007). The TCM Silica gel is widely used in thermochemical applications. It releases the energy inside it by the adsorption process (humidification process). It can be a good option for low expensive TCMs. The endothermic reaction happened by heat sources working with low temperatures $\left(<100^{\circ} \mathrm{C}\right)$, as flat plate solar collectors (Ding, 2012; Mette et al 2012; Vasta et al 2018). There are two types of Zeolites, natural and synthetic. Natural Zeolite is an aluminosilicate mineral and exists in nature (Zhao 2010).

The process of poultry egg incubation consists of two periods, the incubating and hatching period. The incubation period starts from 1 to 18 days, and the three days after 18 days is the hatching period (19-21 days). The range of temperatures during the incubating and hatching period $\left(37.7-39.3{ }^{\circ} \mathrm{C}\right)$ and $\left(37.8-36^{\circ} \mathrm{C}\right)$, respectively. In general, the range of temperatures during incubation should be between (36$39^{\circ} \mathrm{C}$ ) as mentioned by (Okonkwo and Chukwuezie 2012; Kyeremeh and Peprah 2017; Dalangin 2019).

(French 1997). The tolerance of incubation temperature depends on the temperature is low or high, the length of this period, the stage of embryo growth. The embryos are more sensitive to any changes in the first incubation period's temperature in the late period. (Wafadar and Puls 2011) mentioned that the drop in incubation temperature delays the chick hatching but the increase in temperature more harmful.

The relative humidity in the incubator ranged between (50 to 55\%) during the incubated period. At the last three days must be reached to (65-75\%) (Umar et al 2016).
Two types of poultry hatchery machines the first working by electricity and the second with fossil fuels. One of the most critical problems of hatcheries that operate with electricity is the high value of the electricity bill, the power outage, and the unavailability of electricity in remote areas. The hatcheries working by fossil fuel produce harmful gases that influence the embryos and the surrounding environment. As a result, attempts began to use renewable or clean energies to be the energy source needed for the incubation process (Okonkwo and Chukwuezie 2012; Abraham et al 2014; Uzodinma et al 2020). Therefore, from the previous studies, to avoid the electricity costs and negative effects of using fossil fuels. This study aims to apply the thermochemical system as a source of heat needed for the incubation process instead of the traditional source (electricity) or fossil fuel and create a prototype for a poultry incubator and try to provide the conditions for the incubation of poultry eggs.

\section{Materials and Methods}

This research was used as an open system with three types of TCMs that specifications showed in Table 1. The system consists of a working fluid (air) and a TCMs. The system operates at atmospheric pressure. The thermochemical poultry egg incubator prototype consists of three units, the basics component, the thermochemical unit, and the measuring and control unit, as shown in Fig 1.

The first unit consists of a Styrofoam box with dimensions (incubator frame) $(56 \times 39 \times 28.5) \mathrm{cm}$. The egg tray with dimensions $(31 \times 31 \times 5) \mathrm{cm}$ with capacity of 25 eggs, the eggs located horizontally. Turning motor (4 W), (3-4 rpm) equipped with the egg tray to rolling the eggs in a straight line to forward and back as shown in Fig 2. A humidifier (19W), and spray volume $300 \mathrm{ml} / \mathrm{h}$ was used as separate part outside the incubator to supply the incubator with the required humidity levels (5575\%) Fig (1. No.10). The incubator is pro- 
vided with three ventilation holes with a diameter of $1 \mathrm{~cm}$ for each hole and a fan $(12 \mathrm{~V}$ $0.14 \mathrm{~A}$ ) for ventilation and air circulation.

The second unit, the thermochemical unit, consists of four parts.1) The material storage container is made of wood, with dimensions $(35 \times 35 \times 5) \mathrm{cm}$ and capacity $(3.5) \mathrm{kg}$ from TCMs. 2) Vapor pipes, it is made from poly Ethelene Fig (1. No. 8). Three pipes of $2.54 \mathrm{~cm}$ (1 inches/pipe) diameter pass through each hole in the material container. These pipes are perforated (1 mm/bore). 3) The humidification storage material unit Fig (1. No. 4, 5, 6, 7, 8) consists of the water tank ( $2 \mathrm{~L}$ capacity), ultrasonic humidifier, atomizer quantity (250-300 $\mathrm{mL} / \mathrm{h})$, water level $(2.1 \mathrm{~cm}$ above ultra-sonic humidifier body), working temperature (5$45^{\circ} \mathrm{C}$ ), float to maintain the water level in the tank, solenoid valve to supply the water tank by water. The fan (12V DC, $0.14 \mathrm{~A})$ pushes the water vapor to the perforated pipes. 4) Aluminum sheet, the storage material container is covered with an aluminum sheet $(38.5 \times 38.5)$ $\mathrm{cm}$, thickness $0.5 \mathrm{~mm}$, and supplied with fins $(4 \times 5) \mathrm{cm}$ to increase heat exchange between the material and aluminum sheet.

The third unit, measuring unit, and control unit, monitoring unit, and data logging unit. 1) The measuring unit consists of two DHT22 temperature and humidity sensors installed in storage material containers. The first is located in the upper layer of storage material; the second is located in the lower layer in storage material Fig (3). Two DHT22 - temperature and humidity sensors to measure (incubator air and ambient air, temperature and humidity).

DS 18B20 temperature sensors are used DS 18B20 to measure (aluminum sheet surface temperature- temperature between eggs). Moreover, control unit as shown in Fig (4), DS1307 - real-time clock module (RTC) to control turning eggs for (3 seconds per hour). DS 18B20 temperature sensors to control ultrasonic material humidifier switch it off at 40 -C. Humidistat (SK3118-5(0.2) A-24-250Vmade in Italy) to control in incubator humidifier at humidity level (55-75\%). A bulb (40W) was functioned with switch off when the temperature $\geq 37.5{ }^{\circ} \mathrm{C}$ by the sensor DS $18 \mathrm{~B} 20$ is located in the incubator center. 3) Monitoring unit, it used to show the temperature and humidity in various locations during the experiment. 4) Data logging unit, it is used to record the temperature and humidity value every minute. It consists of an Arduino Mega2650 board - microprocessor and microcontrollerDS1307 - real-time clock module (RTC) and SD card module. Generic benetech GM86 LCD display micropower monitor energy meter max $10 \mathrm{~A}-220 \mathrm{~V}$ Ac operating temperature $0-45^{\circ} \mathrm{C}$ was used to measure energy consumption.

Table 1. Specifications of thermochemical materials (TCMs)

\begin{tabular}{|c|c|c|c|}
\hline \multicolumn{5}{|c|}{ Thermochemical materials (TCMs) } \\
\hline Specifications & Silica gel self-indicating & Silica gel-white & Natural Zeolite \\
\hline Synonyms & Adsorbent, Desiccant & $\begin{array}{c}\text { Adsorbent, } \\
\text { Desiccant }\end{array}$ & Adsorbent, Desiccant \\
\hline Size & $(0.841-3.36 \mathrm{~mm})$ & $2-5 \mathrm{~mm}$ & $3-10 \mathrm{~mm}$ \\
\hline Case number & $112926-00-8$ & $63231-674$ \\
$1343-98-2221$ & $\mathrm{SiO}_{2}+\mathrm{nH}_{2} \mathrm{O}$ & $(\mathrm{ca}, \mathrm{k} 2, \mathrm{Na} 2, \mathrm{Mg})_{4} \mathrm{Al}_{8} \mathrm{Si}_{40} \mathrm{O}_{96} \cdot 24 \mathrm{H}_{2} \mathrm{O}$ \\
\hline $\begin{array}{c}\text { Chemical For- } \\
\text { mula }\end{array}$ & $\mathrm{SiO}_{2}+\mathrm{cocl}_{2}$ & $450-750 \mathrm{~kg} / \mathrm{m}^{3}$ & $1150 \mathrm{~kg} / \mathrm{m}^{3}$ \\
\hline Bulk Density & $650-850 \mathrm{~kg} / \mathrm{m}^{3}$ & white & $100 \circ \mathrm{c}-130{ }^{\circ} \mathrm{c}$ \\
\hline Color & $\mathrm{Blue}^{3}-\mathrm{pink}$ & $80-88 \circ \mathrm{c}$ & $38-42 \circ \mathrm{c}$ \\
\hline $\begin{array}{c}\text { Charging tem- } \\
\text { perature }\end{array}$ & $80-88 \circ \mathrm{c}$ & $32-38 \circ \mathrm{c}$ & \\
\hline $\begin{array}{c}\text { Discharging } \\
\text { temperature }\end{array}$ & $32-38 \circ \mathrm{c}$ & & \\
\hline
\end{tabular}

AUJASCI, Arab Univ. J. Agric. Sci., 29(1), 2021 


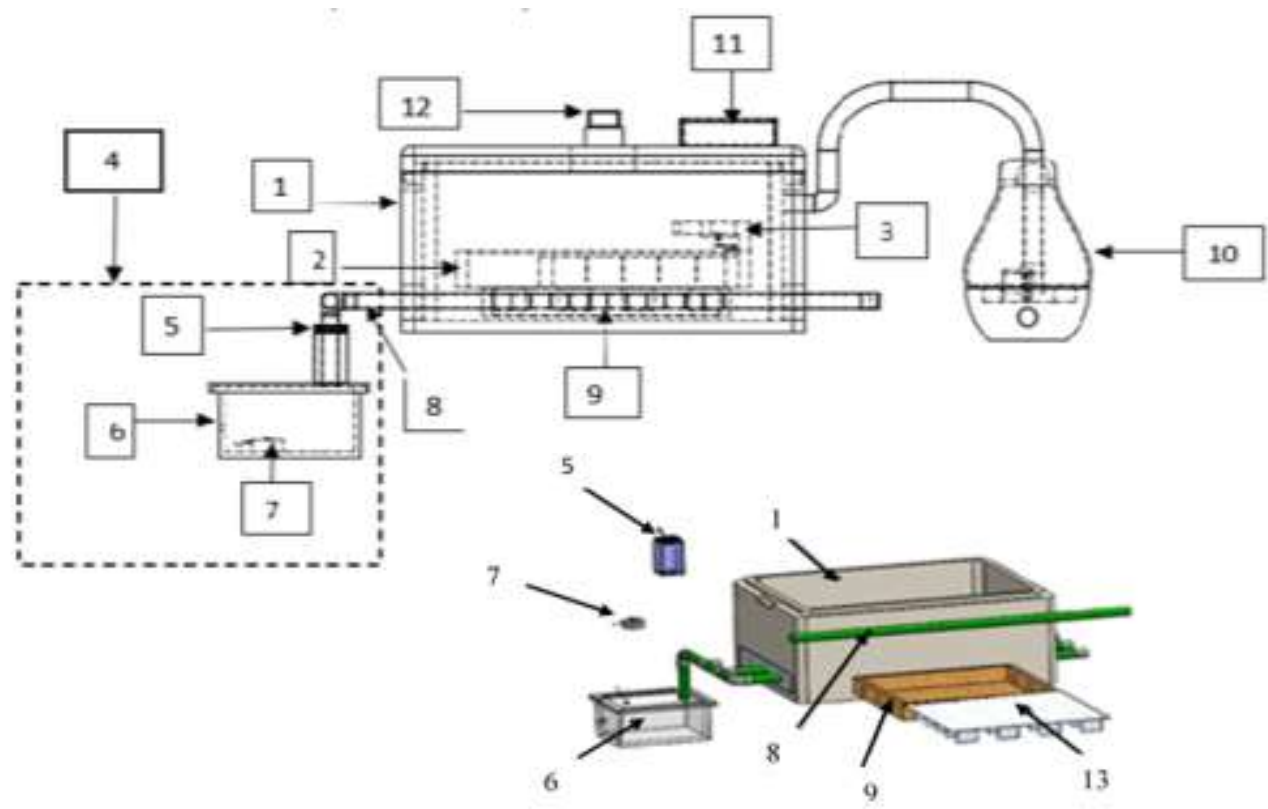

Fig 1. The thermochemical poultry egg incubator prototype components, 1 - The incubator frame, 2eggs tray, 3- turning motor, 4- material humidification unit, 5- fan,6- water tank, 7- ultra-sonic humidifier, 8- vapor pipes (perforated pipes), 9- storage material container (TCMs), 10- humidifier for incubator atmosphere, 11,12- display for temperature and humidity,13- Aluminum sheet
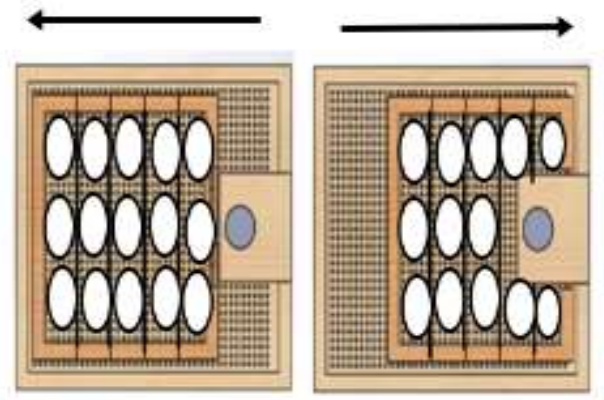

Fig 2. The egg tray with 25 eggs and turning motor capacity, the eggs turn straight forward and back.

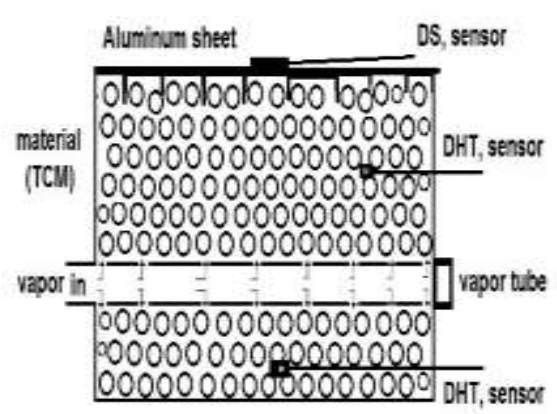

Fig 3. The storage material container covered with aluminum sheets and sensors locations, where: - DS measures aluminum sheet surface temperature, DHT sensor measures storage ma- 


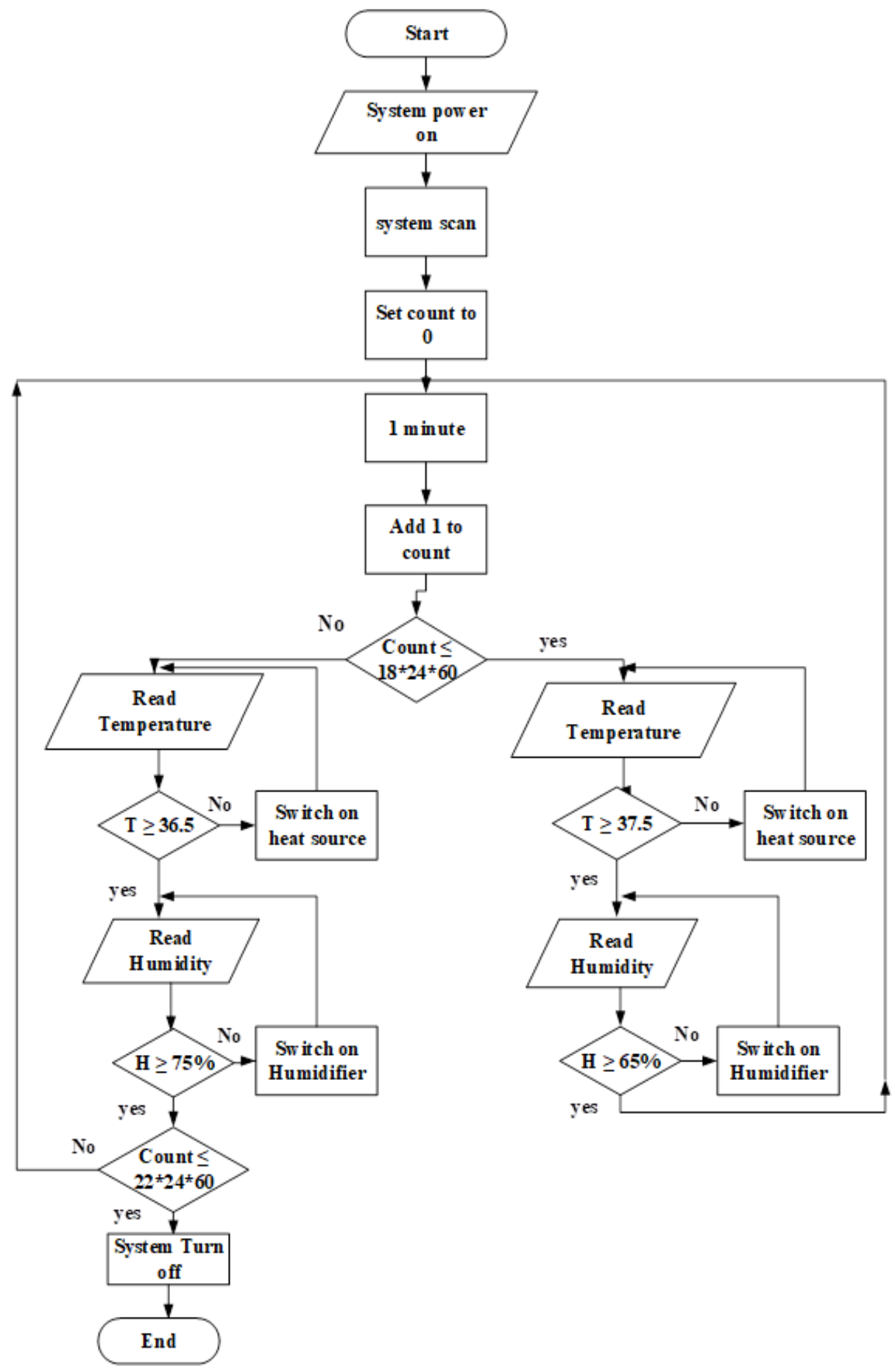

Fig 4. The control of the temperature and humidity inside the thermochemical poultry egg incubator flowchart 
The second incubator was the traditional type of poultry egg incubator poultry model $\mathrm{C} 2$ as shown in Fig 5 made by "PTO incubators industrial company" with maximum power $250 \mathrm{~W}$. The dimensions of incubator were $(57 \times 66 \times 59) \mathrm{cm}$, with capacity 125 hen egg- 76 hatching. The frame of the incubator has special fiber insulated (three layers of insulation) polystyrene panels in high density and reinforced inside. The eggs are turning one cycle/h with angle $45^{\circ}$ clockwise and $45^{\circ}$ anticlockwise direction. The egg tray is made of plastic, with a capacity of 76 hen eggs with dimensions $(34 \mathrm{x} 48) \mathrm{cm}$. Fan located in the one side of incubator; this fan is working to circulate the air to improve temperatures. Electric resistance heater for incubators for the heating process. Digital thermal measurement (sensor) to measure temperature $\left(\mathrm{F}^{\circ}\right.$ or $\left.\mathrm{C}^{\circ}\right)$. Hygrometer used to read relative humidity. The ventilation happens by two holes, one on the left side and another in the incubator's backside.

During this experiment, using DHT22 temperature \& humidity sensors located in the poultry egg incubator center to measure incubator air temperature and humidity. DS
18B20 - temperature sensors located in the center of egg tray between eggs to measure the eggs' temperature. As shown in Fig 6.

\subsection{Energy analysis for recovered thermal process}

A working fluid can recover the energy released by the exothermic reaction in an open thermal energy storage (TES) system. The working fluid in the open system is humid air. When the ultra-sonic humidifier produces water vapor, the fan pushes it into the vapor pipes. The water vapor comes out of the holes in the perforated pipes located inside the material. The water vapor combines with the material, which produces heat that is transferred to the aluminum sheet that covers the material, then to the egg tray installed on the aluminum sheet.

The energy transferred by the material is happened by conduction between the layers of material $\left(R_{\text {cond1 }}\right)$ then between the material surface and the aluminum sheet $\left(\mathrm{R}_{\text {cond2 }}\right)$, then from the aluminum sheet to the incubator air by convection $\left(\mathrm{R}_{\text {conv }}\right)$ as shown in Fig $\mathbf{7}$.

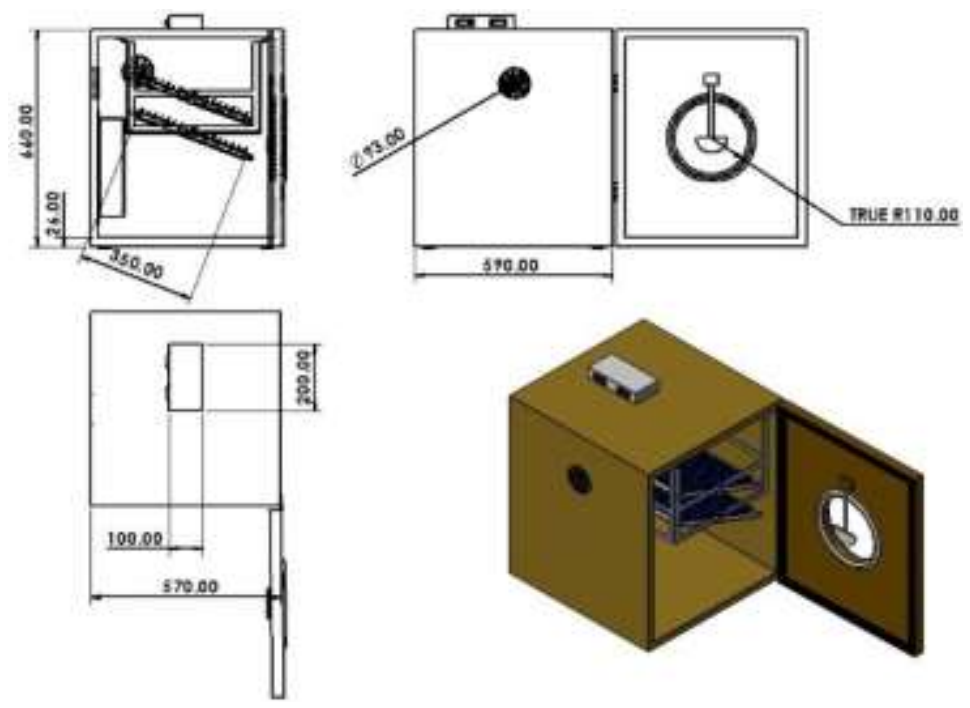

Fig 5. The traditional poultry egg incubator 


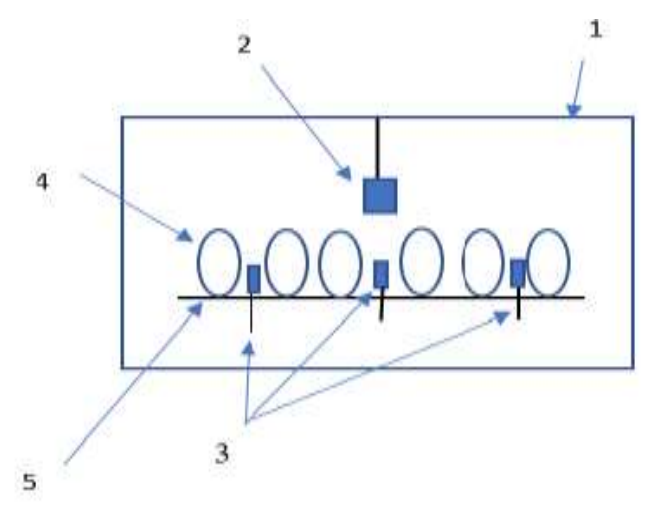

Fig 6. sensors location inside traditional poultry egg incubator, 1-incubator body, 2- DHT22 - temperature \& humidity sensors, 3- DS 18B20 - temperature sensors, 4- egg, 5- egg tray

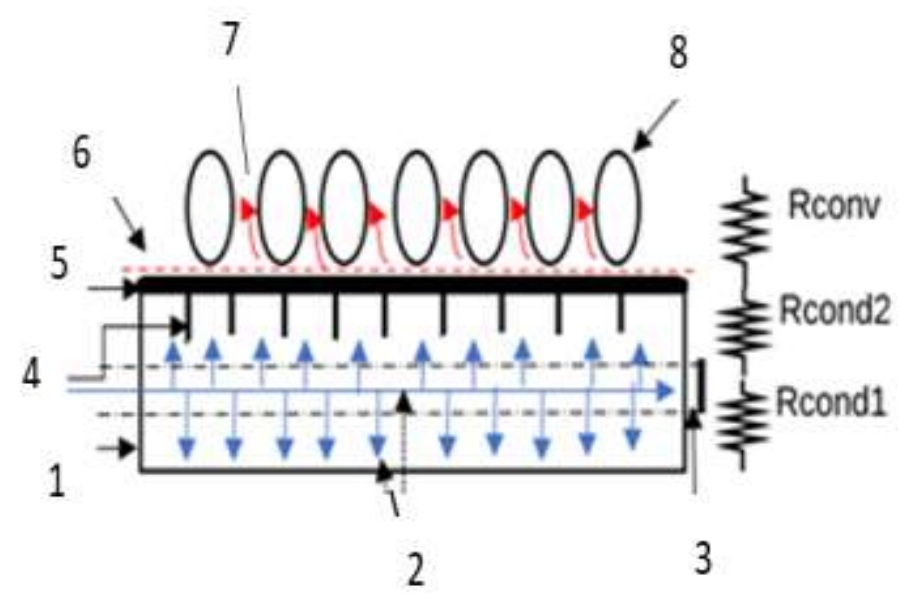

Fig 7. Illustration of the process of recovering thermal process and heat transfer from TCM to the aluminum sheet to eggs where: - 1- the storage material container, 2- vapor flow, 3- perforated vapor pipes, 4- fins, 5- aluminum sheet, 6the egg tray, 7- heat flow, 8- egg

Where: $\mathrm{R}_{\text {cond } 1,2}$ is the thermal resistance by conduction, and $\mathrm{R}_{\text {conv }}$ is the thermal resistance by convection, ${ }^{\circ} \mathrm{C} / \mathrm{W}$. It can be expressed using the following equation to calculate the thermal energy recovered from the material:

$$
\text { Qout }_{=} h_{a} A_{a l}\left(T_{a l}-T_{a i r}\right)
$$

Where: Qout is the heat released by (TCMs), W. $h_{a}$ is the convection heat transfer coefficient, $\left(\mathrm{W} / \mathrm{m}^{2} \cdot{ }^{\circ} \mathrm{C}\right) . A_{a l}$ is the surface area of aluminum sheet, $\mathrm{m}^{2} . T_{a l}$ and $T_{\text {air }}$ is the temperature surface of aluminum sheet and the air temperature inside the incubator, ${ }^{\circ} \mathrm{C}$. It can calculate $h_{a}$ as forced convection as shown in the following equation:

$$
\begin{aligned}
& h_{a}=\frac{N_{u} K_{a i r}}{l_{c}} \\
& R_{e}=\frac{u_{\infty} l_{c}}{v}
\end{aligned}
$$


Where: $N_{u}$ is the Nusselt number, $K_{\text {air }}$ is the air thermal conductivity, $\mathrm{W} / \mathrm{m} .{ }^{\circ} \mathrm{C} . \mathrm{l}_{\mathrm{C}}$ is the characteristic length, $m . R_{e}$ is the Reynolds number. $U_{\infty}$ is the air velocity, $\mathrm{m} / \mathrm{s} . l_{c}$ is the characteristic length, m. $v$ is the air kinematic velocity, $\mathrm{m}^{2} / \mathrm{s}$.

\subsection{The Total heat requirement for poultry egg incubator}

The following equation can be used to calculate the total heat required for incubation (Victor Ukaamaka et al 2015; Osanyinpeju et al 2016; Demissie 2020).

$$
\mathrm{Q}_{\mathrm{t}}=\mathrm{Q}_{\mathrm{a}}+\mathrm{Q}_{\mathrm{e}}+\mathrm{Q}_{\mathrm{v}}+\mathrm{Q}_{\mathrm{s}}
$$

Where, $Q_{t}$ is the total heat required for incubation, $\mathrm{W} . \mathrm{Q}_{\mathrm{a}}$ is the heat required to raise the temperature of incubator air, W. Qe is the heat required to raise the temperature of the egg from ambient temperature to incubation temperature, W. Qv is the heat loss by ventilation, W. Qs is the heat losses throw the walls of the incubator, W.

\subsubsection{The heat required to raise the temper- ature of incubator air $\left(Q_{a}\right)$}

$$
Q_{a}=M_{a} C_{p}\left(T_{f}-T_{i}\right)
$$

Where: Ma is the mass of air, $\mathrm{kg}$. Cp is the specific heat of air, $\mathrm{kJ} / \mathrm{kg}$. ${ }^{\circ} \mathrm{C} . \mathrm{T}_{\mathrm{i}}$ is the initial air incubator temperature $\left(20^{\circ} \mathrm{C}\right)$. $\mathrm{T}_{\mathrm{f}}$ the final incubator temperature or the incubation temperature $\left(38^{\circ} \mathrm{C}\right)$.

The warming rate expressed about the raising of egg temperature from room temperature to incubation temperature with the time. It can be calculated by the following equation (Woldegiorgis and Meyyappan, 2018).

$$
\begin{gathered}
\text { The warming rate }= \\
\frac{\left(T_{f}-T_{i}\right)}{\text { time needed for raising the temperature }}
\end{gathered}
$$

2.2.2. The heat required to raise the egg's temperature from ambient temperature to incubation temperature $(\mathrm{Qe})$

$$
Q_{e}=n M_{e} C_{p}\left(T_{i e}-T_{o e}\right)
$$

Where: $\mathrm{n}$ is the number of eggs. $\mathrm{M}_{\mathrm{e}}$ is the weight for the egg as an average of $60 \mathrm{~g}$. $\mathrm{C}_{\mathrm{p}}$ is the specific heat of egg $\left(3.23 \mathrm{~kJ} / \mathrm{kg}\right.$. $\left.{ }^{\circ} \mathrm{C}\right)$ as mentioned in (ASHREA HandbookRefrigeration 2014). $\mathrm{T}_{\mathrm{ie}}$ is the egg temperature inside the incubator, ${ }^{\circ} \mathrm{C}$. $\mathrm{T}_{\mathrm{oe}}$ is the egg temperature outside the incubator, ${ }^{\circ} \mathrm{C}$.

The warming rate expressed about the raising of egg temperature from room temperature to incubation temperature with the time. It can be calculated by the following equation.

$$
\begin{gathered}
\text { The warming rate }= \\
\frac{(\text { Toe-Tie) }}{\text { time needed for rasing the temperature }}
\end{gathered}
$$

(Lourens et al 2006) mentioned that, due to the activities of metabolic the embryo produced heat production at day18 $137 \mathrm{~mW} / \mathrm{egg}$ and $155 \mathrm{~mW} / \mathrm{egg}$. In this study an average of heat production $146 \mathrm{~mW} /$ egg was used.

\subsubsection{The heat losses by ventilation $(Q v)$}

The levels of oxygen, carbon oxide, and relative humidity affect the embryo development, so ventilation is so essential to keep these factors within the applicable limit (Daud et al 2019). The number of times the air is changed depends on the development of the embryos and their needs of $\mathrm{O}_{2}, \mathrm{CO}_{2}$ and relative humidity. So, the changes of air per hour $(\mathrm{ACH})$ can be once/3h as mentioned by (Mauldin 2002; Osanyinpeju et al 2016) or once/2hours (Daud et al 2019) but (Woldegiorgis and Meyyappan 2018) showed that the suitable value $4 \mathrm{ACH}$. The losses of heat by ventilation can be expressed as follows:

$$
Q_{v}=V \rho_{a} C_{p}\left(T_{i}-T_{o}\right)
$$




\section{Using Thermochemical Materials as a Heat Source for Poultry Egg Incubation}

To determine the mass of air, it can use this equation.

$$
\rho_{a}=\frac{M_{a}}{V}
$$

Where: $\mathrm{V}$ is the air volume changed, $\mathrm{m}^{3} . \rho_{\mathrm{a}}$ is the density of outlet air (Agidi et al 2014). Cp is the air specific heat capacity $\mathrm{kJ} / \mathrm{kg}$. ${ }^{\circ} \mathrm{C} . \mathrm{T}_{\mathrm{i}}$ and $\mathrm{T}_{\mathrm{O}}$ is the air temperature inside and outside the incubator, ${ }^{\circ} \mathrm{C}$.

\subsubsection{The heat losses through the walls of incubator Qs}

The heat losses through the incubator walls happen in three ways conduction, convection, and radiation. It can use the following equation to calculate the heat losses through the incubator walls.

$$
Q_{S}=\frac{T_{\infty 1}-T_{\infty 2}}{\sum R_{t h}}=\frac{T_{\infty 1}-T_{\infty 2}}{R_{\text {rad }}+R_{\text {conv }}+R_{\text {cond }}}
$$

Where: $\mathrm{T}_{\infty 1}$ is the ambient temperature (room temperature), ${ }^{\circ} \mathrm{C} . \mathrm{T}_{\infty 2}$ is the air temperature inside the incubator, ${ }^{\circ} \mathrm{C} . \mathrm{R}_{\text {rad }}, \mathrm{R}_{\text {conv, }}$ and $\mathrm{R}_{\text {cond }}$ are the thermal resistance by radiation, convection, and conduction, ${ }^{\circ} \mathrm{C} / \mathrm{W}$.

The following equation was used to calculate the losses through incubator walls that happens by radiation.

$$
R_{\text {rad }}=\frac{1}{h_{\text {rad }} A}
$$

Where: $\mathrm{R}_{\mathrm{rad}}$ is the thermal resistance by radiation, ${ }^{\circ} \mathrm{C} / \mathrm{W}$. $\mathrm{h}_{\mathrm{rad}}$ is the radiation heat transfer coefficient $\left(\mathrm{W} / \mathrm{m}^{2} . \mathrm{K}\right) . \mathrm{A}_{1}$ is the surface area of the incubator wall, $\mathrm{m}^{2}$.

$$
h_{\text {rad }}=\varepsilon \mathrm{A}_{s} \delta\left(T_{s 1}+T_{\text {sur }}\right)\left(T_{s 1}^{2}+T_{\text {sur }}^{2}\right)
$$

Where: $\varepsilon$ is the surface emissivity, $0 \leq \varepsilon \leq 1$. As is the surface area, $\mathrm{m}^{2} . \delta$ is the Stefan-Boltzmann constant; $\delta=5.67 * 10^{-8} \mathrm{~W} / \mathrm{m}^{2}$. $\mathrm{K}^{4}$. Ts is the surface temperature, $\mathrm{K} . \mathrm{T}_{\text {sur }}$ is the surrounding temperature, $\mathrm{K}$.

The radiation and convection losses happen to parallel, so; it must calculate equivalent resistance $\mathrm{R}_{\mathrm{eq}}$.

$$
R_{e q}=\left(\frac{1}{R_{\text {conv }}+R_{\text {rad }}}\right)^{-1}
$$

The losses through incubator walls that happen by forced convection can be calculated by the following equations.

$$
R_{\text {conv }}=\frac{1}{h A}
$$

Where: $R_{\text {conv }}$ is the thermal resistance by convection, ${ }^{\circ} \mathrm{C} / \mathrm{W}$. $\mathrm{h}$ is the convection heat transfer coefficient $\left(\mathrm{W} / \mathrm{m}^{2} .{ }^{\circ} \mathrm{C}\right) . \mathrm{A}_{1}$ is the surface area, $\mathrm{m}^{2}$.

$$
\mathrm{h}_{1}=\frac{\mathrm{N}_{\mathrm{u}} \mathrm{K}_{\mathrm{air}}}{\mathrm{l}_{\mathrm{c}}}
$$

Where: $\mathrm{N}_{\mathrm{u}}$ is the Nusselt number, $\mathrm{K}_{\mathrm{air}}$ is the air thermal conductivity, $\mathrm{W} / \mathrm{m} .{ }^{\circ} \mathrm{C} . \mathrm{l}_{\mathrm{C}}$ is the characteristic length, $\mathrm{m}$.

$$
R_{e=} \frac{\mathrm{u}_{\infty} \mathrm{l}_{\mathrm{c}}}{\mathrm{v}}
$$

Where: $\mathrm{R}_{\mathrm{e}}$ is the Reynolds number. $\mathrm{u}_{\infty}$ is the air velocity, $\mathrm{m} / \mathrm{s} . l_{c}$ is the characteristic length, $\mathrm{m} . v$ is the air kinematic velocity, $\mathrm{m}^{2} / \mathrm{s}$.

\subsection{The energy consumption and costs}

Total operating cost $=$ total power consumption (kW.h) $\mathrm{x}$ the cost of unity (LE/ kW.h). (18)

Energy saving $=($ traditional incubator total energy consumption - thermochemical incubator total energy consumption) / traditional incubator total energy consumption. (19)

\subsection{The biological performance for the in- cubation process}

It can be expressed the biological performance by calculating the percentage of hatchability the poultry eggs as shown in Eq. (20). (Osanyinpeju et al 2016; Saravanan and Pasupathy 2016; Dalangin 2019; Uzodinma et al 2020). 
Hatchability $\%=$

$\frac{\text { the total number of eggs hatched }}{\text { the total number of fertile eggs }} \times 100$

\section{Results and Discussions}

This study contains two experiments. The first experiment's target was to test the storage materials or TCMs ability to provide suitable thermal conditions for the incubation process without eggs. To achieve this target, 1) The TCMs was humidified to release the recovered thermal that stored inside it and measured the temperature of the material, the surface of aluminum sheet and the places where the eggs were located, 2) The calculation of both the rate of humidification and the recovered thermal. The recovered thermal period (retention time) for storage materials. 3) Select the suitable storage material for the incubation process.

The second experiment was incubation eggs by TCMs as the source of heat. The temperature and relative humidity were measured and controlled around 21 days of incubation.

\subsection{The first experiment without egg}

\subsubsection{The thermal energy recovered from TCMs}

The optimal thermal energy recovered as shown in Fig (8) from thermal storage materials (Silica gel self-indicating, white Silica gel, and Natural Zeolite) were 0.0612, 0.0437 and, $0.074 \mathrm{kWh} / \mathrm{kg}$, respectively. It can be observed that the amount of recovered thermal is small in the beginning because the amount of moisture saturation is also small. With time, the saturation of material increases, and the amount of recovered thermal increases to reach its maximum value and then begin to decrease. This curve can help determine the time needs to replace the saturated storage material with a new activated TCM.

The recovered thermal process lasted for six days for storage materials Silica gel selfindicting and Natural Zeolite. The cumulative recovered thermal energy from storage media (Silica gel self-indication, Silica gel white, and Natural Zeolite) were $0.165,0.080$, and 0.124
$\mathrm{kWh} / \mathrm{kg}$, respectively. In general, the cumulative recovered thermal for Silica gel self-indicating higher than Natural Zeolite and white Silica gel by $0.041,0.085 \mathrm{kWh} / \mathrm{kg}$, respectively. Commercial white Silica gel recovered thermal did not remain more than three days. The thermal energy recovered decrease after the second day, due to the non-reversible damage happened to the particles of commercial white Silica gel (broke into minimal parts).

\subsubsection{Calculation thermal recovery through storage materials humidification rate}

With an increasing humidification rate of storage material, the thermal recovered energy of storage material increases as the storage material temperature increases. The temperature of TCMs and recovered thermal reach to the maximum value decreases with increasing humidification rate, as shown in Figs $(\mathbf{9 , 1 0 , 1 1 )}$. This result means that the storage material does not need to be fully saturated to release all the energy inside it. This curve can be helped to determine the humidification rate required for the storage material to produce the maximum temperature and recovered thermal.

\subsubsection{The storage material temperatures and incubation temperature.}

The optimal temperature difference between the incubating and hatching period around $1.5^{\circ} \mathrm{C}\left(37.5-36^{\circ} \mathrm{C}\right)$, so the incubation thermal tolerance $\pm 0.75^{\circ} \mathrm{C}$. As shown in Fig (12), the delta temperature fluctuations for the storage material Natural Zeolite are located between the range of incubation thermal tolerance. On the other side, the delta temperature fluctuations of storage materials (Silica gel self-indicating and white Silica gel) were out of the range of incubation thermal tolerance in some periods.

When following storage materials temperatures as shown in Fig (13) during the recovered thermal process, it can be observed that the maximum and minimum temperatures for (Silica gel self-indicating, white Silica gel, and Natural Zeolite) were $\left(33.52-37.3^{\circ} \mathrm{C}\right)$, (32.5- 


\section{Using Thermochemical Materials as a Heat Source for Poultry Egg Incubation}

$\left.35.67^{\circ} \mathrm{C}\right)$, and $\left(34.83-36.4^{\circ} \mathrm{C}\right)$, respectively. The TCM Silica gel self-indicating has the advantage that its temperature increases gradually and reaches the maximum and gradually decreases. The TCMs Natural Zeolite and white Silica gel temperature at the first increase, then decrease then increase again. So, it can say the temperature distribution for storage material Silica gel self-indicating better than Natural Zeolite and white Silica gel. From the previous results, the total recovered thermal of storage material Silica gel self-indicating was bigger than Natural Zeolite and white Silica gel. After the recovered thermal process, Silica gel self-indicating did not experience any kind of damage as happened in white Silica, which makes it suitable for a new cycle. The age of recovered thermal process for white
Silica gel did not exceed three days compared with the age of recovered thermal process for Silica gel self-indicating and Natural Zeolite were six days. The temperature distribution of Silica gel self-indicating was better, as shown in Fig (13).

\subsubsection{The aluminum sheet surface and eggs location temperature with storage materials}

The egg location temperature with storage materials (Silica gel self-indicating, Silica gel white, Natural Zeolite) used as heat source for heating prototype incubator as shown in Fig (14). The closest temperature to the reference (incubation temperature) where the Silica gel, which means low additional heat required for heating process.

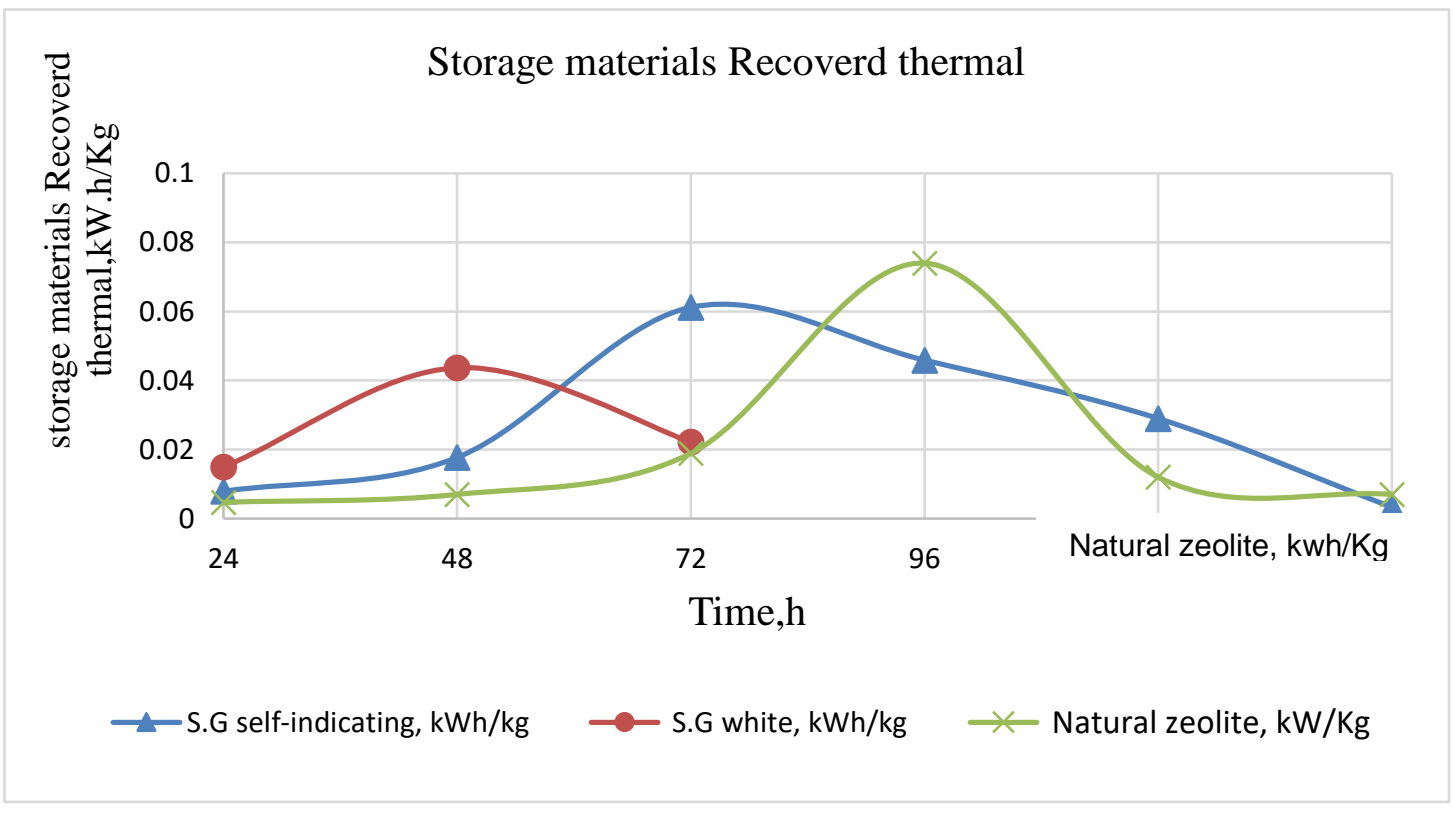

Fig 8. Illustrate the recovered thermal, in (kW.h/kg) of storage materials (Silica gel self-indicating, Silica gel white, and Natural Zeolite) during the time 


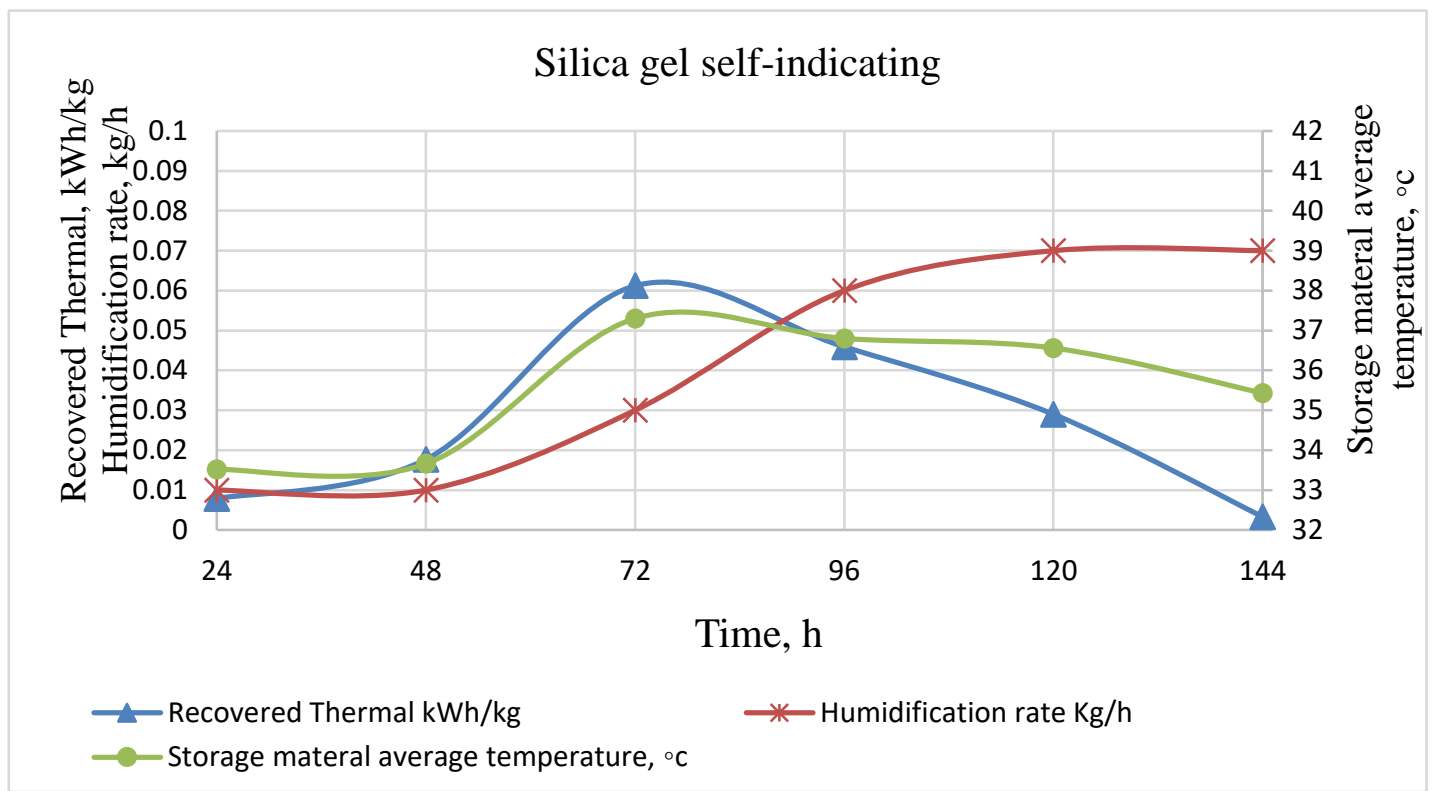

Fig 9. The recovered thermal and temperature of storage material with humidification rate of storage material (Silica gel self-indicating)

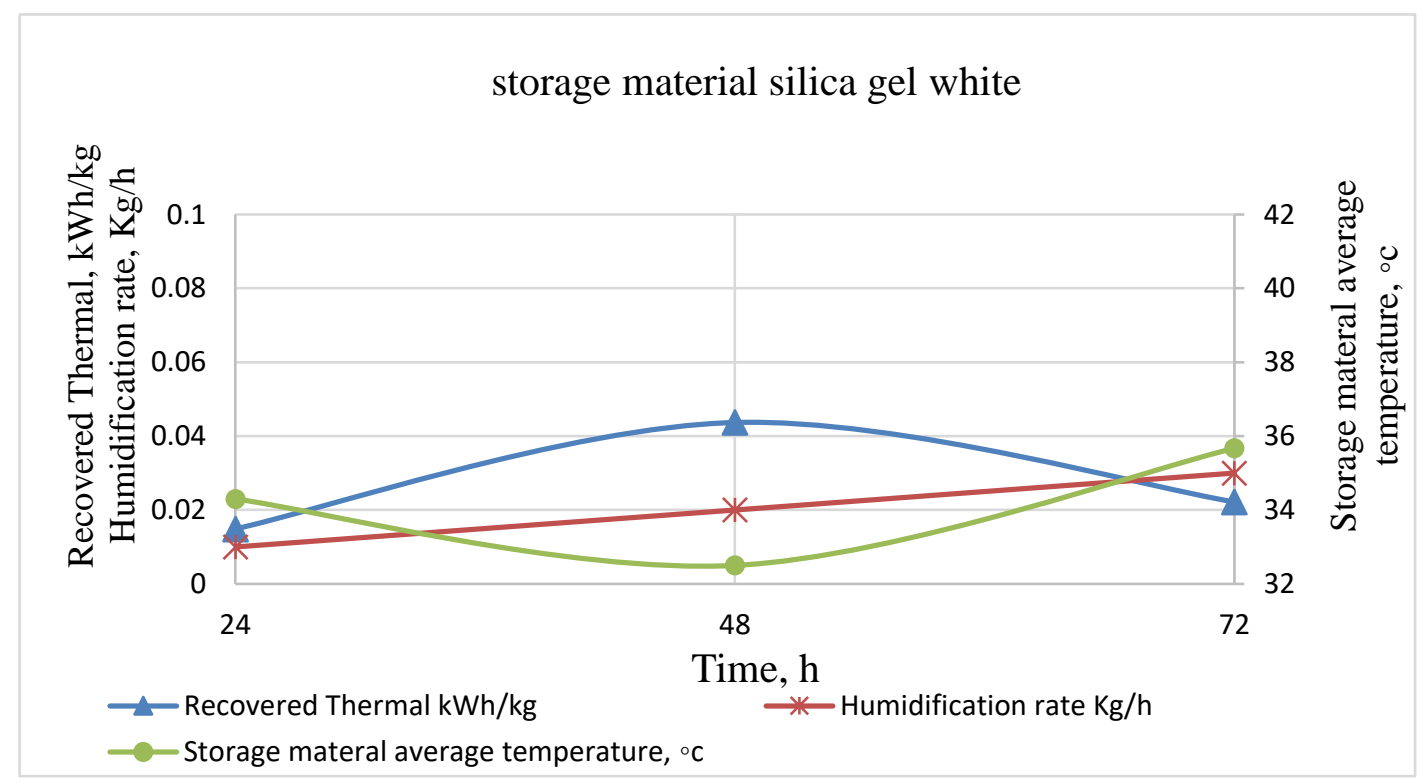

Fig 10. The recovered thermal and temperature of storage material with humidification rate of storage material (commercial white Silica gel) 


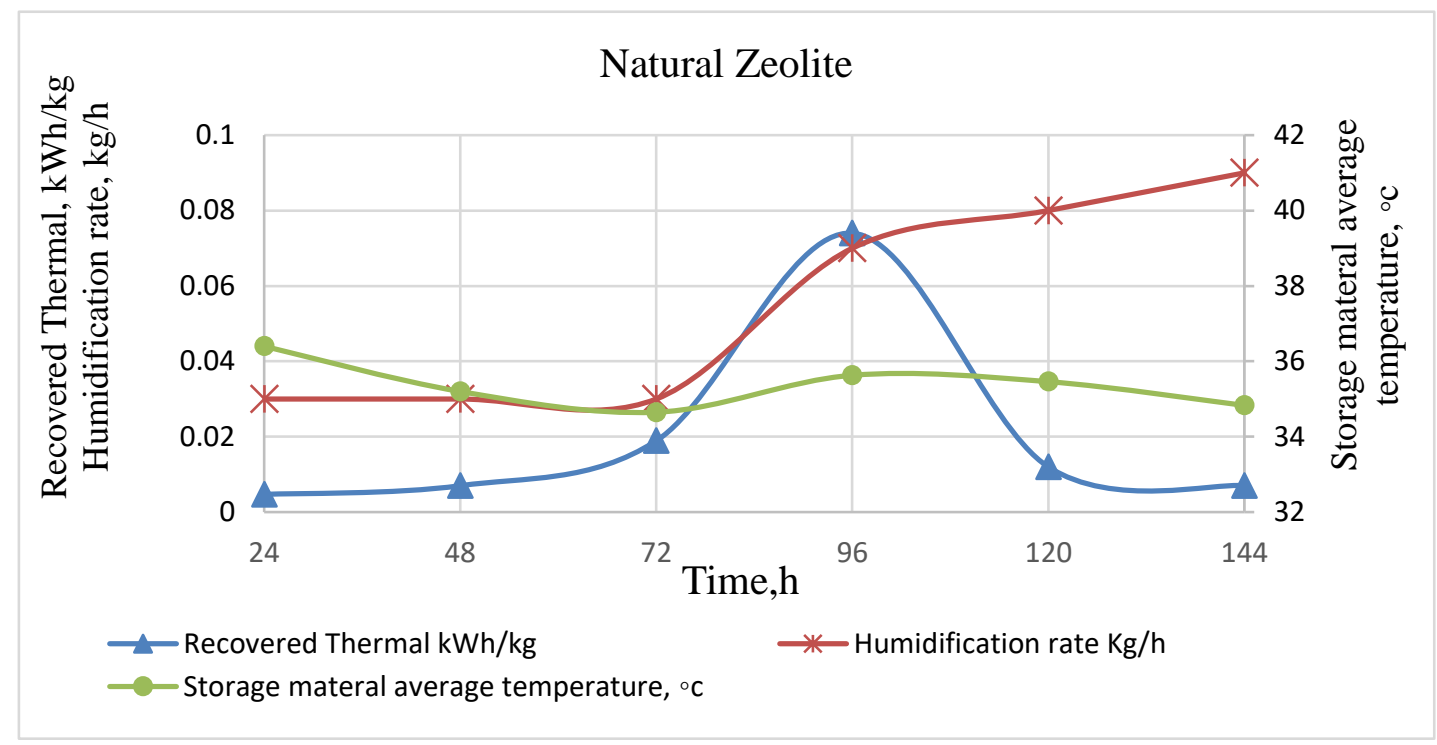

Fig 11. The recovered thermal and temperature of storage material with the humidification rate of storage material (Natural Zeolite)

\section{Delta temperature for storage materials}

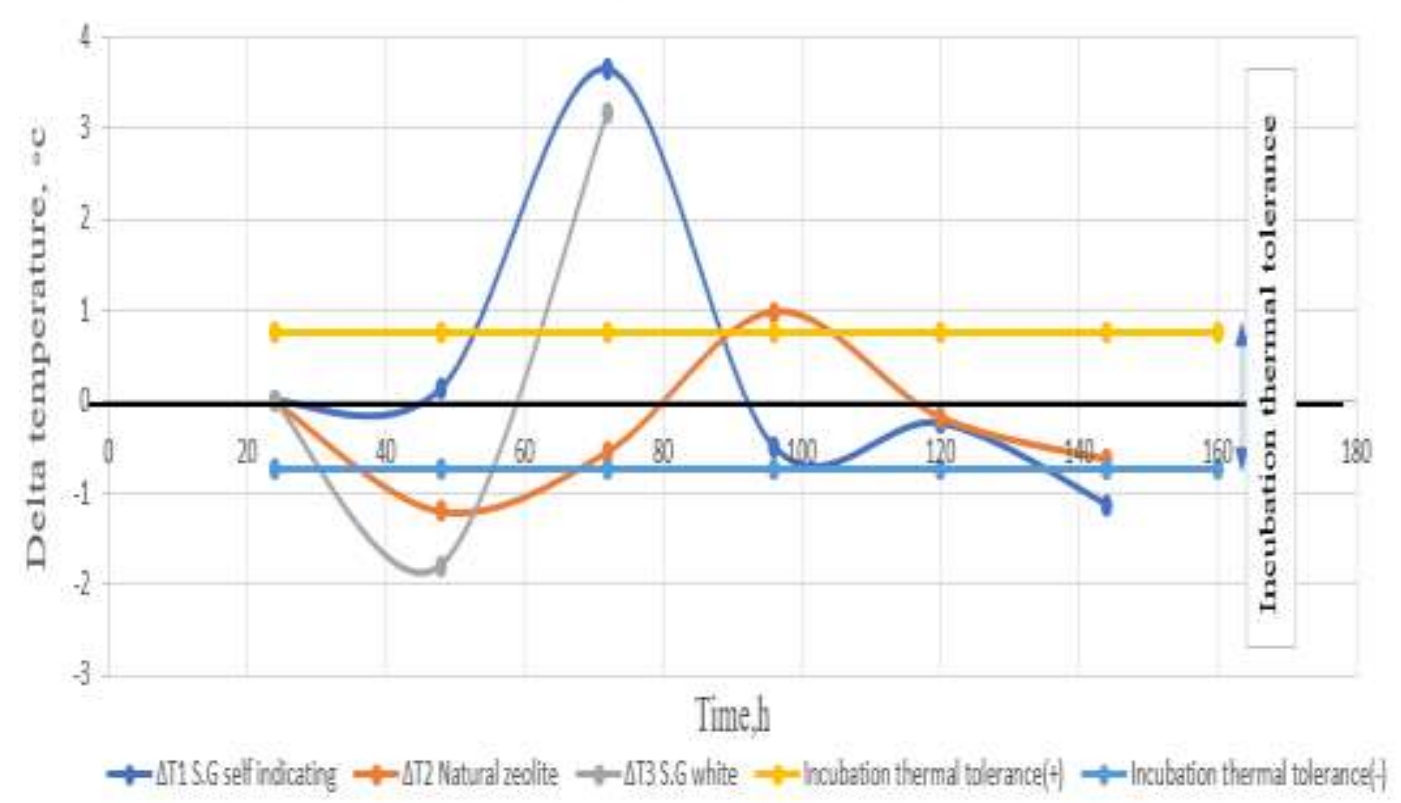

Fig 12. Delta temperature for storage material (Silica gel self-indicating, white Silica gel and Natural Zeolite) and incubation thermal tolerance for chicken eggs 


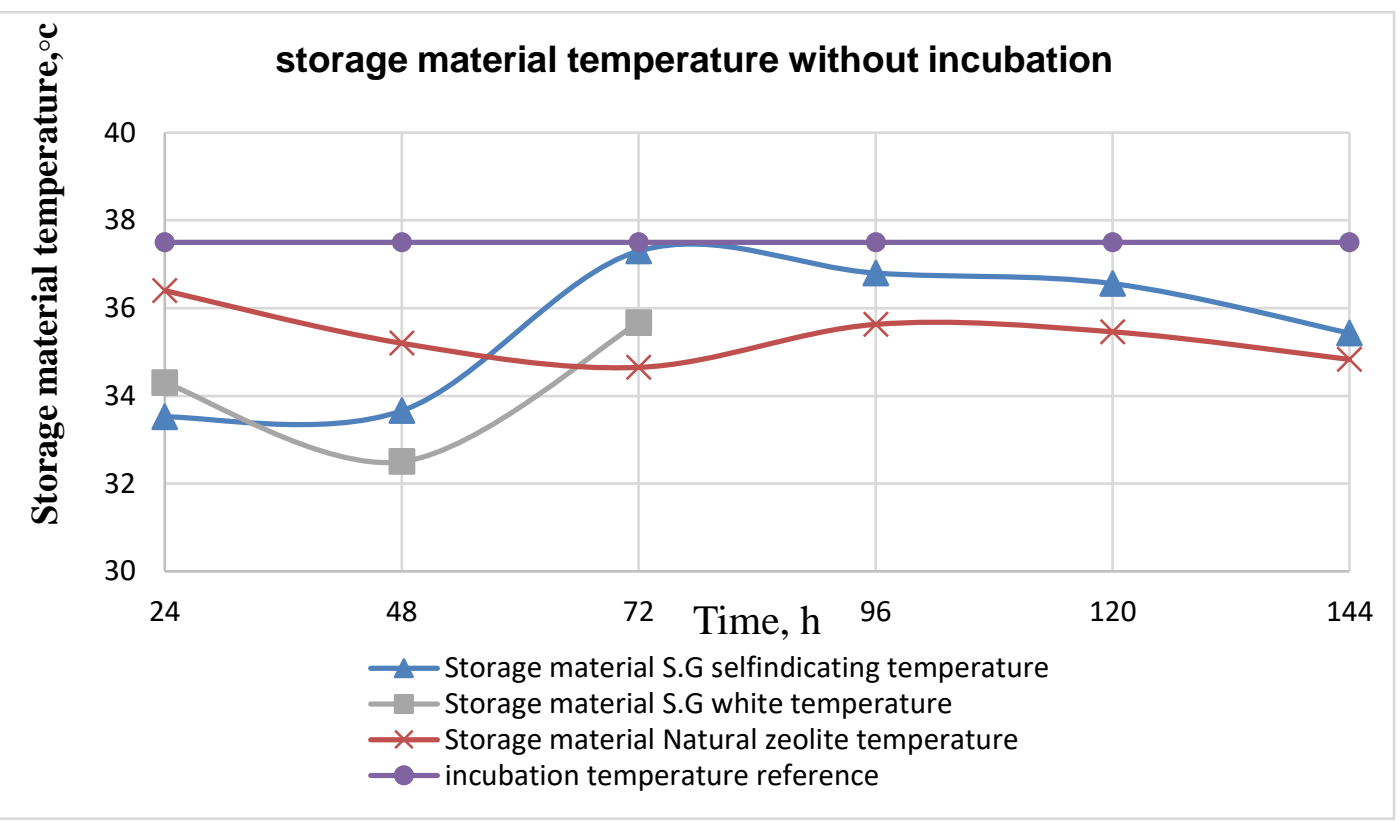

Fig 13. Storage material temperatures during recovered thermal process and incubation temperature

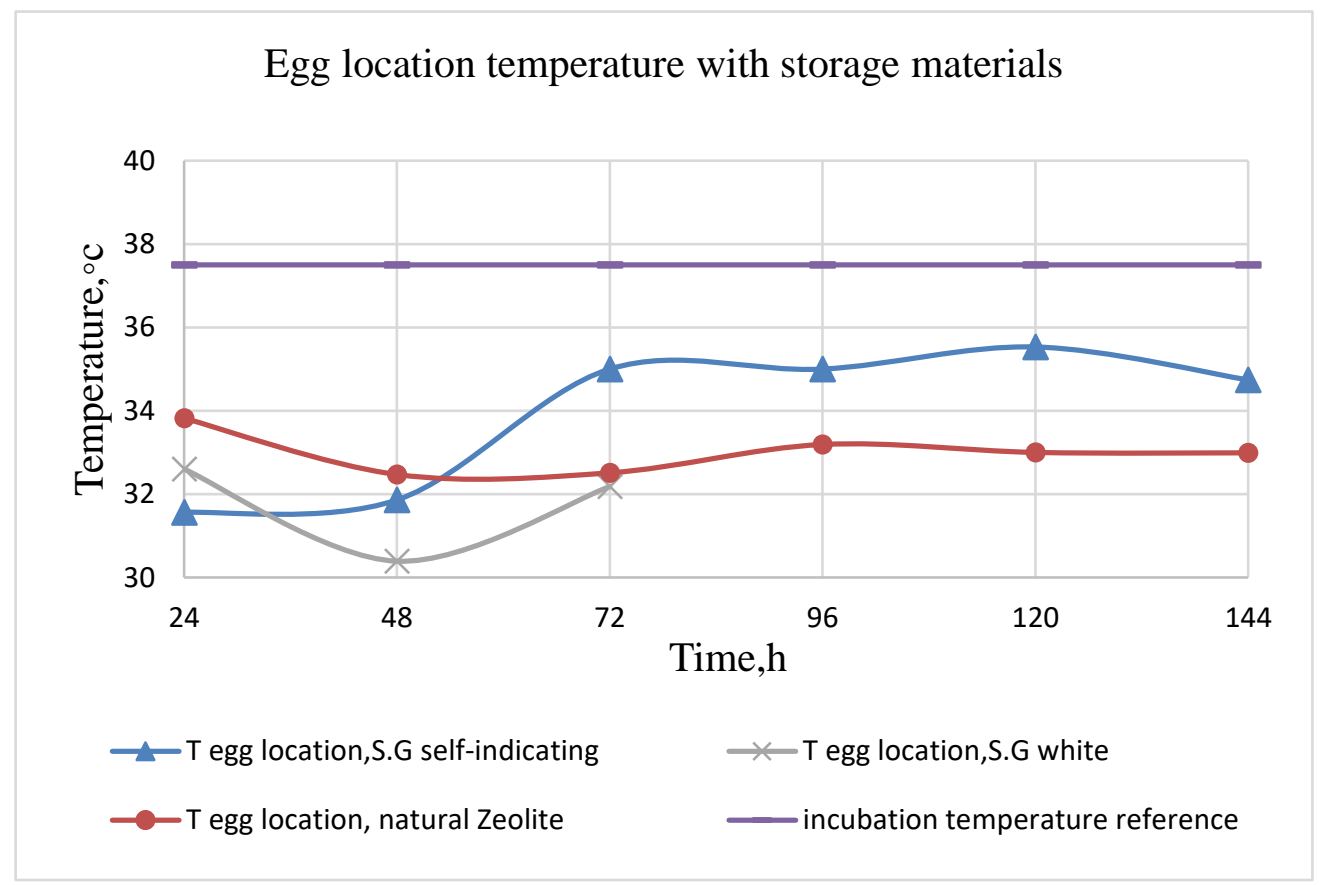

Fig 14. The egg location temperature with storage materials (Silica gel self-indicating, Silica gel white, Natural Zeolite) 
The range of temperatures in egg location $\left(31.56-35.53^{\circ} \mathrm{C}\right)$ was less than the optimal incubation temperature $\left(37.5^{\circ} \mathrm{C}\right)$ by using Silica gel self-indicating. as shown in Fig 15. This result due to the maximum average temperature of Silica gel self-indicating was $37.3^{\circ} \mathrm{C}$, as shown in Fig 9. Before and after this period, Silica gel self-indicating's average temperature was $\left(33.52,33.66^{\circ} \mathrm{C}\right)$ and $\left(36.8,35.43{ }^{\circ} \mathrm{C}\right)$. This decrease in material temperature influences by aluminum's temperature sheet surface and egg location. As a result of this, it is necessary to use an additional heat source with the thermochemical system to maintain the temperature at its desired levels during the incubation process.

\subsection{The poultry egg incubation with TCM}

\subsubsection{The total heat required for poultry egg incubator}

The total energy needed for the incubation process was $(36.09 \mathrm{~W})$ calculated by Eq. No. (4). The results showed that the total heat required to raise the air temperature calculated by Eq. No. $(5,6)$ from ambient temperature to incubation temperature was $0.56 \mathrm{~W}$. The energy required to raise the egg temperature calculated by Eq. No. $(7,8)$ from room temperature to incubation temperature was $24.23 \mathrm{~W}$. The heat loss by ventilation calculated by Eq. No. (9-10) was $1.5 \mathrm{~W}$ at ACH (air change per hour) $4 \mathrm{ACH}$. The total loss calculated by Eq. No. (11:17) from the incubator wall by conduction, convection, and radiation was $9.8 \mathrm{~W}$. The embryo heat production due to metabolic was $3.65 \mathrm{~W}$ for 25 eggs.

3.2.2. The temperatures inside thermochemical prototype and traditional incubator

The average temperature between eggs in the thermochemical prototype and traditional incubator as shown in Fig $\mathbf{1 6}$ at incubation period (1-18 day) was $\left(35.1-37.6^{\circ} \mathrm{C}\right)$ and (37.9- $\left.38.5^{\circ} \mathrm{C}\right)$, respectively. The average temperature between eggs at the hatching period (1821) was $\left(36.4-37.0^{\circ} \mathrm{C}\right)$ and $\left(38.0-38.4^{\circ} \mathrm{C}\right)$, respectively, at average ambient temperature $\left(23.5-29.5^{\circ} \mathrm{C}\right)$. The average temperature between eggs in prototype was more fluctiuation compared to the traditional incubator. The range of temperature flactiuation in prototype and traditional incubator was $2.5^{\circ} \mathrm{C}$ and $0.6^{\circ} \mathrm{C}$, respectively.

\subsubsection{The relative humidity inside the ther- mochemical prototype and traditional incu- bator}

The relative humidity inside the poultry egg incubator one of the factors affecting on hatchability process. As shown in Fig 17, the average relative humidity inside the thermochemical prototype and traditional incubator during the incubation period was (55.7-61.5\%) and (57-65.5\%), respectively. During hatching period was (61.4-69.4\%) and (59-62.3\%), respectively, at an ambient relative humidity (37.4-54.4\%). (Ogunwande et al 2015) mentioned that, the moisture level must be in the range (50-55\%) for the first 18 days and $(65 \%)$ during hatching period. The levels of moisture inside the prototype were controlled around 21 days of incubation. So, the level of humidity required can be controlled according to the stage of growth of the embryos. The levels in humidity inside the traditional incubator not controlled but depend on suppling the evaporation pan by water manually, due to that, it is difficult to raise the humidity levels in the hatching period.

\subsubsection{The biological performance of ther- mochemical prototype and traditional incu- bator}

The two incubators have the same capacity of eggs (total incubated eggs $=25$ eggs/incubator). The average weight was $60 \mathrm{~g}$ were obtained from a commercial layer breeder flock (Hy-Line W-36) at 38 weeks of age (WOA). The results of hatching showed in Table (2). 
The percent of hatchability calculated by Eq. No. (20). The percent of hatchability of prototype incubator lower than traditional incubator due to the temperature fluctuations inside prototype more than traditional incubator. (Wafadar and Puls 2011) showed that, the optimal temperature during the first two weeks of incubation process is $38.5^{\circ} \mathrm{C}$ with tolerance \pm $0.5^{\circ} \mathrm{C}$. The temperature fluctuation more than $0.5{ }^{\circ} \mathrm{C}$ effect on the hatchability percentage. (Decuypere et al 2001) mentioned that, the range of the temperature achieves the highest hatchability is $\left(37^{\circ} \mathrm{C}-38^{\circ} \mathrm{C}\right)$. As shown in the previous results the temperature fluctuations in prototype incubator were more than $0.5^{\circ} \mathrm{C}$ which affected on the percent of hatchability.

\subsubsection{The energy consumption and opera- tion costs for thermochemical prototype and traditional incubator}

The energy consumption for thermochemical prototype and traditional incubator was measured by the energy meter. The total energy consumption (for 21 days), thermochemical prototype and traditional incubator was $11.2 \mathrm{kWh}$ and $19.25 \mathrm{kWh}$, respectively. The ratio of energy saving was calculated by Eq. No (19) and the value was $41.8 \%$.

The total operating cost for incubation process can be calculated by Eq. No. (18). The total cost for thermochemical prototype and traditional incubator was 7.28 and 12.51 L.E, respectively at unity cost $0.65 \mathrm{~L}$.E as cited in the Ministry of Electricity and Energy's official website.

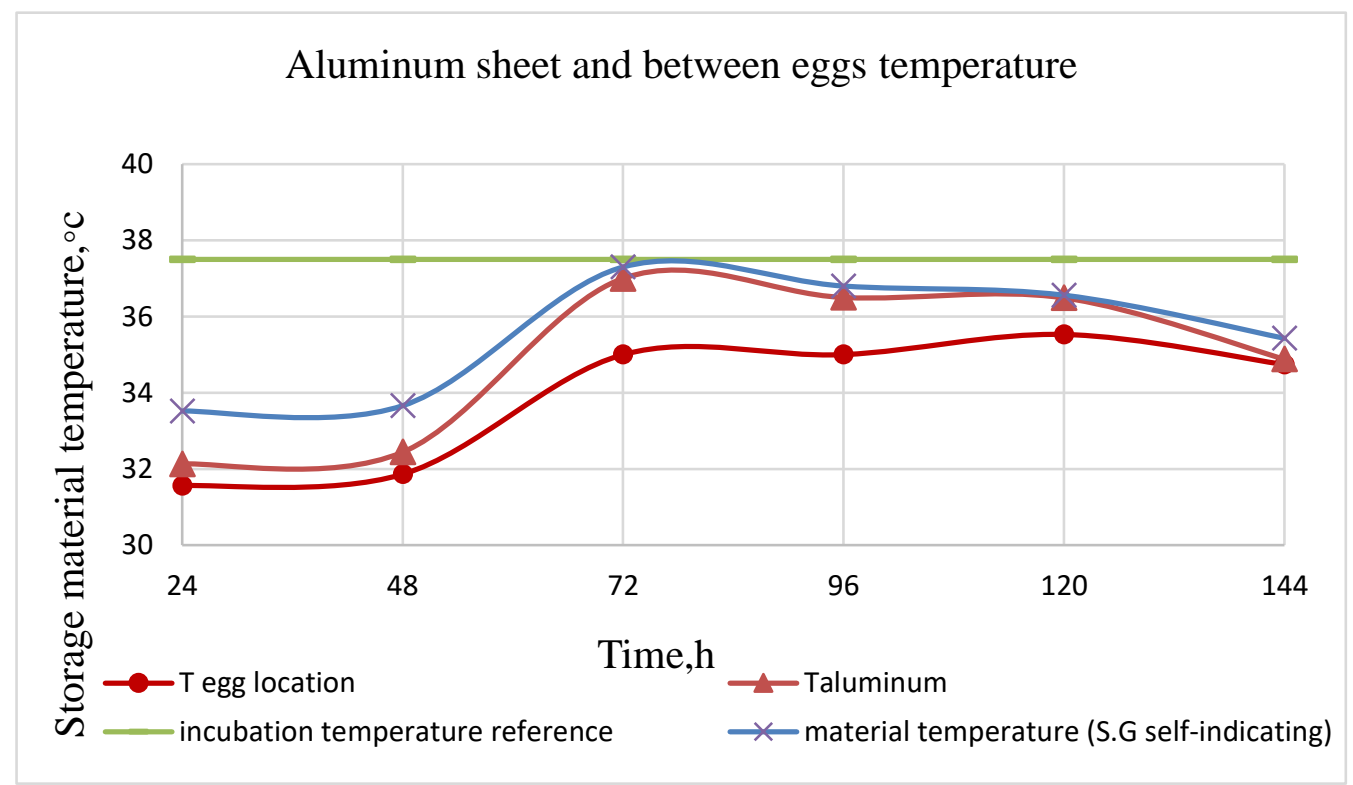

Fig 15. The average temperature for aluminum sheet and eggs location with storage material Silica gel self-indicating 


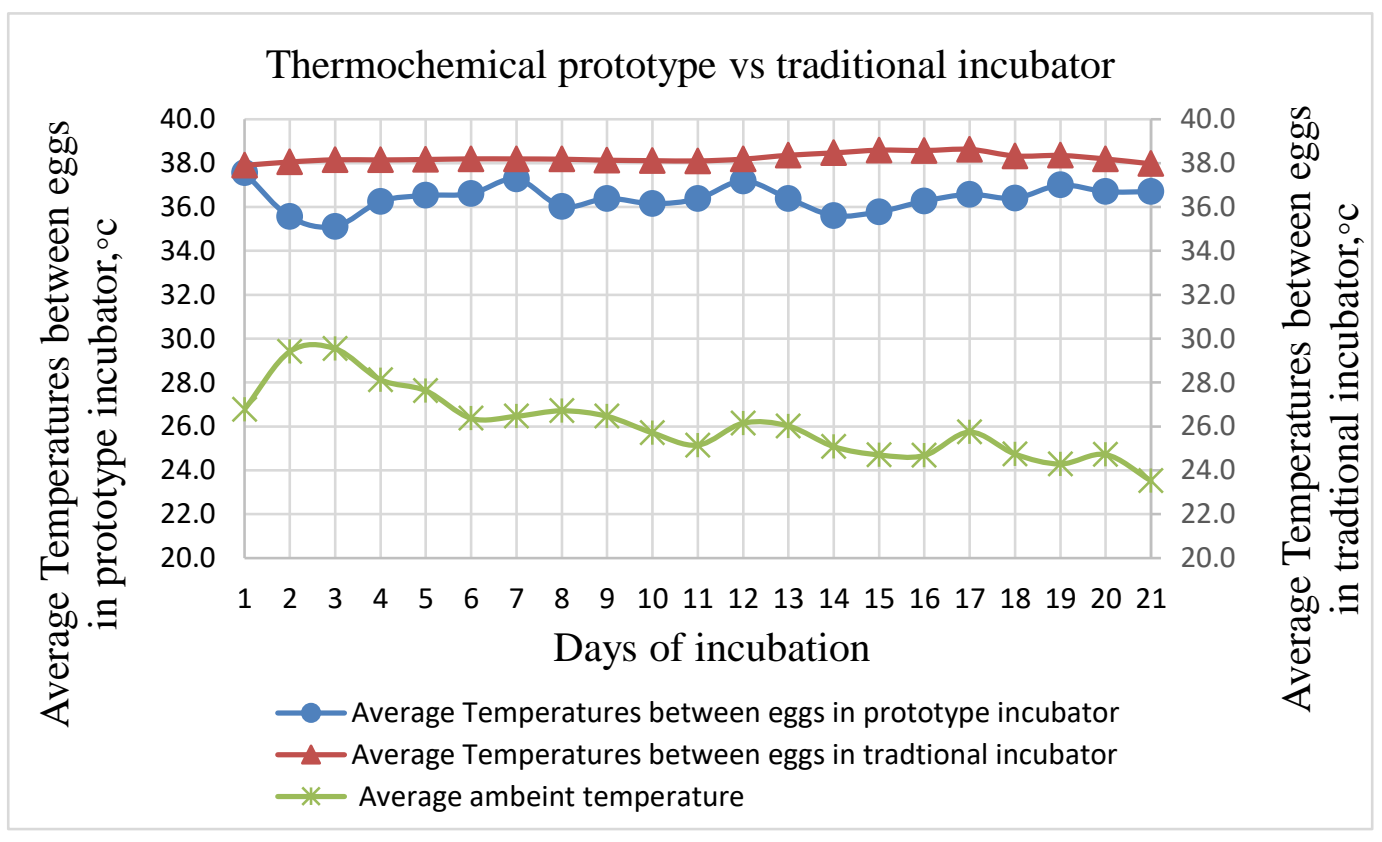

Fig 16. The average of temperature between eggs in thermochemical prototype and traditional incubator

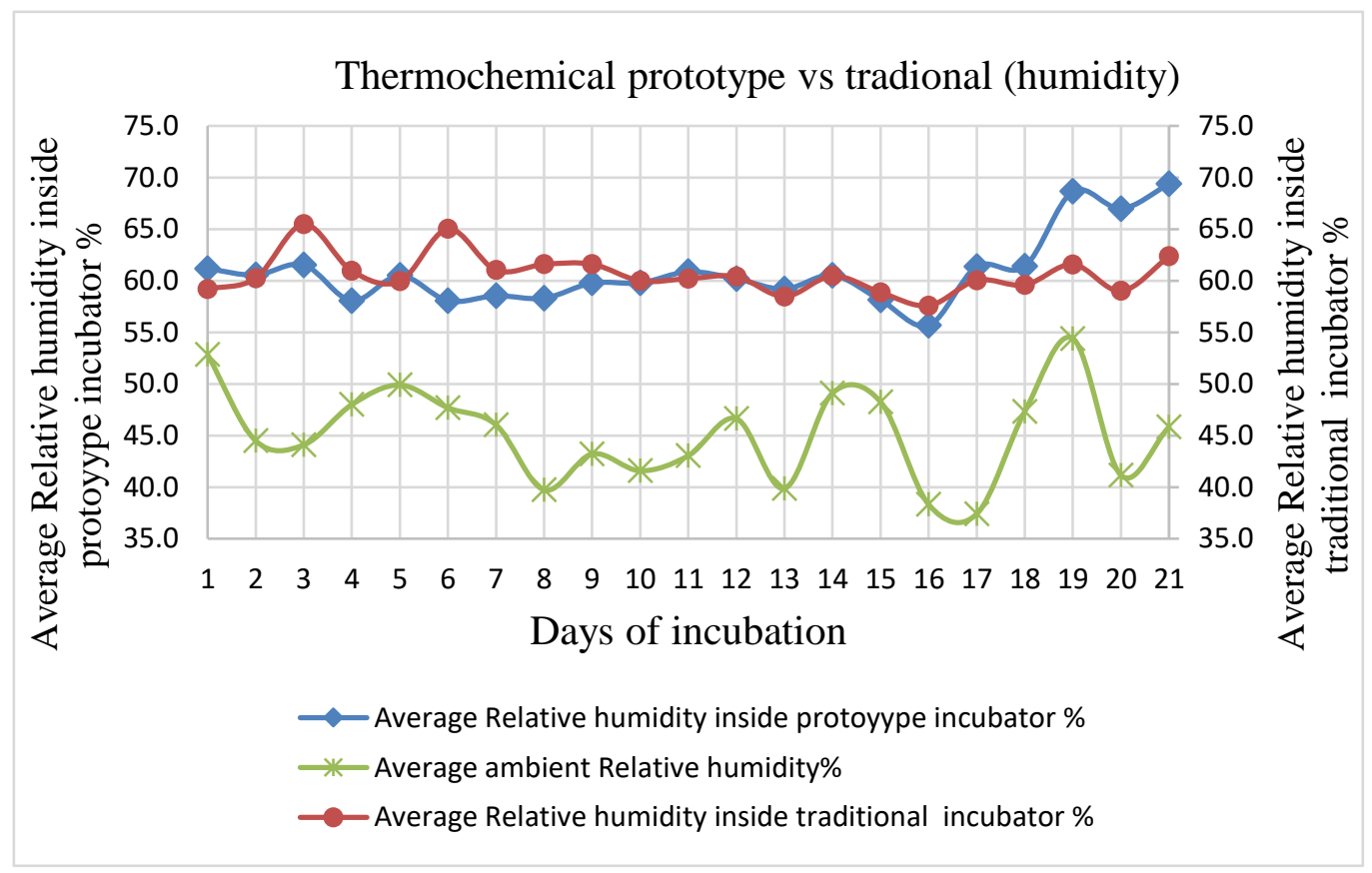

Fig 17. The average relative humidity inside the thermochemical prototype and traditional incubator 
Table 2. The results of hatching in prototype and traditional incubator

\begin{tabular}{|c|c|c|c|c|c|c|}
\hline Incubator & $\begin{array}{c}\text { No. of } \\
\text { fertile egg }\end{array}$ & $\begin{array}{c}\text { No. of } \\
\text { infertile } \\
\text { egg }\end{array}$ & $\begin{array}{c}\text { Early } \\
\text { death }\end{array}$ & $\begin{array}{c}\text { Late } \\
\text { death }\end{array}$ & $\begin{array}{c}\text { No. of } \\
\text { hatched } \\
\text { egg }\end{array}$ & $\begin{array}{c}\text { Psercentage } \\
\text { of } \\
\text { hatchability } \\
\text { \% }\end{array}$ \\
\hline Prototype & 14 & 11 & non & 4 & 10 & 71.4 \\
\hline Traditional & 21 & 4 & 1 & 3 & 17 & 80.95 \\
\hline
\end{tabular}

\section{References}

Abraham, NT; Mathew, SL; Kumar, CAP (2014) Design and implementation of PV poultry incubator using PLC. Telkomnika Indonesian Journal of Electrical Engineering $12,4900-4904$.

Agidi, G; Liberty, JT; Gunre, ON; Owa, GJ (2014) Design, construction and performance evaluation of an electric powered egg incubator. IJRET: International Journal of Research in Engineering and Technology 3, 521-526.

Dalangin, FAT (2019) Performance evaluation of the developed solar powered poultry egg incubator for chicken. Journal of Science, Engineering and Technology 6, 67-81.

Daud, RMNHR; Sidek, M N; Zain, MYM; Kassim, A H (2019) The development of automatic forced air egg incubator. e-Academia Journal 8, 101-108.

Decuypere, E; Tona, K; Bruggeman, V; Bamelis, F (2001) The day-old chick: a crucial hinge between breeders and broilers. World's Poultry Science Journal, 57, 127-138.

Demissie, TN (2020) Sizing of solar photovoltaic for mechanical and thermal energy of automatic egg incubator. International Journal of Scientific \& Engineering Research 11, 7182.

Ding, Y (2012) Thermochemical energy storage technologies for building applications : a state-of-the-art review. International Journal of Low-Carbon Technologies 8, 106-116.
French, NA (1997) Modeling incubation temperature: the effects of incubator design, embryonic development, and egg size. Poultry science 76, 124-133.

Haji Abedin, A (2010) Thermochemical energy storage systems: modelling, analysis and design. Ph.D. in Mechanical Engineering, Mechanical Engineering Dept, Fac. of Engineering and Applied Science, Ontario Institute of Technology University, pp 8-10.

Handbook-Refrigeration, ASHRE (2014) American Society of Heating, Refrigerating and Air-Conditioning Engineers. Chapter 34, 34.1.

Hauer, A (2007) Sorption theory for thermal energy storage. Thermal Energy Storage for Sustainable Energy Consumption. pp 393-408.

Kyeremeh, F; Peprah, F (2017) Design and construction of an arduino microcontrollerbased egg incubator. International Journal of Computer Applications, springer, Dordrecht 168, 15-23.

Lourens, A; Molenaar R; van den Brand, H; Heetkamp, MJW; Meijerhof R; Kemp, B (2006) Effect of egg size on heat production and the transition of energy from egg to hatchling. Poultry Science 85, 770-776.

Mauldin, JM (2002) Factors affecting hatchability.Commercial Chicken Meat and Egg Production,Springer, Boston pp 727-773.

Mette, B; Kerskes, H; Drück, H (2012) Concepts of long-term thermochemical energy storage for solar thermal applications Selected examples. Energy Procedia. Elsevier, pp 321-330. 


\section{Using Thermochemical Materials as a Heat Source for Poultry Egg Incubation}

Ogunwande, GA; Akinola, EO; Lana, AR (2015) Development of a Biogas-powered poultry egg incubator. Ife Journal of Science 17, 219-228.

Okonkwo WI; Chukwuezie OC (2012) Characterization of a photovoltaic powered poultry egg incubator. 4th International Conference on Agriculture and Animal Science.Singapore 10.

Osanyinpeju, K; Aderinlewo, A.; Adetunji, O; Ajisegiri, E (2016) Development of Solar powered poultry egg incubator. College of Engineering International Conference Federal University of Agriculture Abeokuta p 11.

Saravanan, MR; Pasupathy, A (2016) Incorporation of phase change material (PCM) in poultry hatchery for thermal management \& energy conversion schemes of slaughterhouse waste in Broiler farms for energy conservation - A case study. International Conference on Energy Efficient Technologies for Sustainability, (ICEETS), IEEE, pp 291-299.

Umar, AB; Lawal, K; Mukhtar, M; Adamu, MS (2016) Construction of an electricallyoperated egg incubator. International Journal of Modern Engineering Sciences 5, 1-18.
Uzodinma, EO; Ojike, O; Etoamaihe, UJ; Okonkwo, WI (2020) Performance study of a solar poultry egg incubator with phase change heat storage subsystem.Thermal Engineering, p. 100593.

Vasta, S; Brancato, V; La Rosa, D; Palomba, V; Restuccia, G; Sapienza, A; Frazzica, A (2018) Adsorption heat storage: state-of-theart and future perspectives. Nanomaterials 8, pp 522.

Victor, AU; Ukaamaka, NT; Echi, OS (2015) Development and evaluation of a passive solar system for poultry egg incubation. International Journal of Engineering Research and General Science 3, 748-760.

Wafadar, F; Puls, I (2011) Improving hatching and brooding in small-scale poultry keeping. Wageningen, Netherlands: Agromisa Foundation and CTA. p 44.

Woldegiorgis, MM; Meyyappan, V (2018) Conceptual design of solar incubator integerated with thermal energy storage for poultry farming. International Research Journal of Natural and Applied Sciences 46, 2349-4077.

Zhao, X (2010) Porous materials for direct and indirect evaporative cooling in buildings. $M a$ terials for Energy Efficiency and Thermal Comfort in Buildings Woodhead Publishing pp 399-426. 


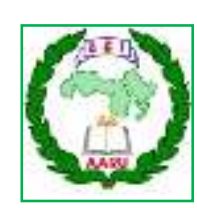

262
مجلة اتحاد الجامعات العربية للعلوم الزراعية، جامعة عين شمس، القاهرة، مصر مجلد(29)، عدد(1)، 243 - 262، 2021 المعة

Website: http://ajs.journals.ekb.eg

DOI: 10.21608/ajs.2021.54048.1313

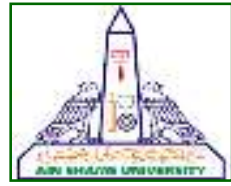

استخدام المواد الكيميائية الحرارية كمصدر حرارة لحضانة بيض الدواجن

شيماء عبدالفتاح حسن 1" - مبارك محمد مصطفى 1 - محمود زكي العطار 1 - مروه شعبان عبده2 2

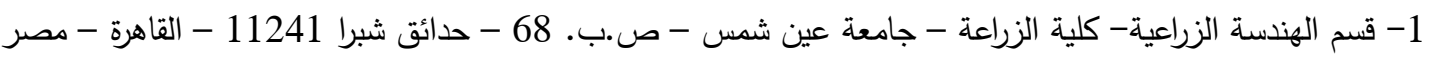
2- قسم إنتاج الدواجن - كلية الزراعة - جامعة عين شمس - ص.ب. 68 - حدائق شبرا 11241 - القاهرة - مصر

*Corresponding author: shimaa_abdelrazek@agr.asu.edu.eg

Accepted 19 April, 2021

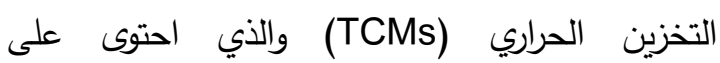

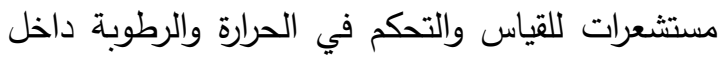

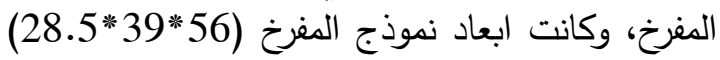

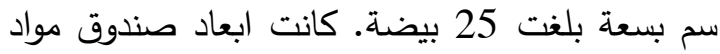
التخزين الحراري (35*35*5) سم بسعة 3.5 كجم

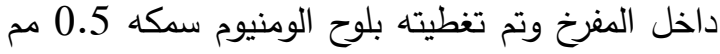

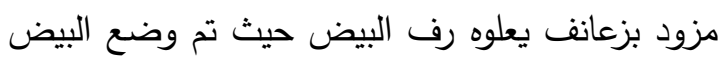

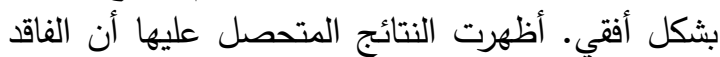

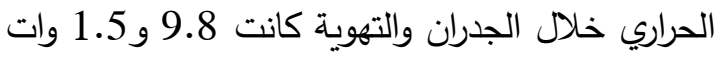
على التوالي بينما كان الناتج الحراري للبيض خلان التلال عمليات الايض 3.65 وات. الطاقة الكلية اللازمة لعملية التثريخ كانت 36.09 وات. بلغ استهلاك الطاقة خلاتل 21 يوم للمفرخ التقليدي 19.25 كيلووات.اتعاعة وللنموذج 11.2 كيلووات.ساعة. وحقق المفرخ التجريبي وفر للطاقة بنسبة 41.8\% وذلك بالمقارنة مع المفرخ التقليدى. كانت نسبة الفقس للمفرخ التقليدي 80.9 وللتجريبي 71.4\%

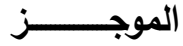

تهدف هذه الدراسة الى الاستفادة من قدرة بعض المواد الكيميائية على تخزين الطاقة الحرارية (TCMs)

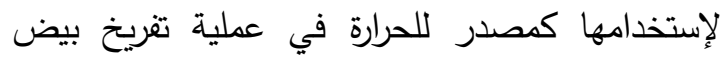
الدواجن. تم إستخدام ثلاث أنواع من الـ (TCMs) كوسط

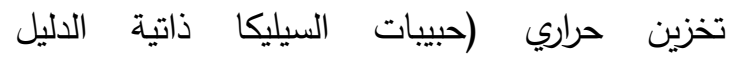

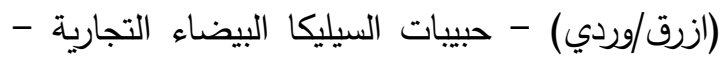

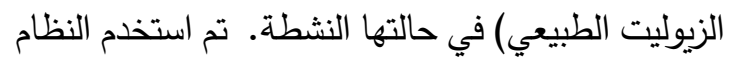

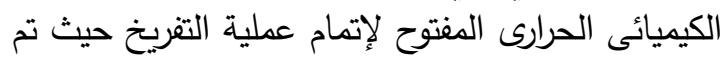
ترطيب المواد ببخار ماء ناتج عن مرطب لإنب يعمل بالموجات فوق الصوتية عند الضغط الجواء لنوي. وكانت عملية الإسترداد الحراري تهدف الى إطلاق الطاق الطاقة المختزنة في هذه المواد (TCMs). تم إستخدام مفرخان خلال التجربة. مفرخ تقليدي يعمل بالكهرباء بأبعاد

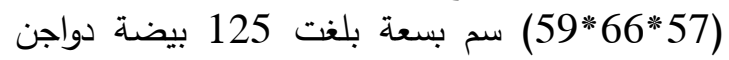
وسعة تفقيس 76 بيضة. نموذج لمفرخ يعمل بمواد 